\title{
A Stratified Percolation Model for Saturated and Unsaturated Flow through Natural Fri ctures
}

\author{
L. J. Pyrak-Nolk, 'N. G. W. Cook, ${ }^{2,3}$ and L. R, Mye? \\ 'Department of Earth and Atmospheric Sciences \\ Purdue University \\ West Lafayette, Indiana 47907 \\ ${ }^{2}$ Eurth Sciences Division \\ Lawrence Berkeley Laboratory \\ University of Californis \\ Berkeley, California 94720 \\ ${ }^{3}$ Department of Materials Science \\ and Mineral Engineering \\ University of Califomia
}

January 1990

This work was supported by the Director, Ofice of Enerty Reseurch, Ofice of Basic Enerty Sciences, Engineering and Geociences Division, and by the Director, Onice of Civilian Redionctive Wave Management, Office of Facilities Siting and Development, Siting and Facilities Technolosy Division, of the U.S. Depurtment of Energy under Contract No. DE-AC03-76SF00098. 


\section{A STRATIFIED PERCOLATION MODEL FOR SATURATED AND UNSATURATED FOW THROUGH NATURAL FRACTURES}

\author{
L. J. PYINAK-NOLTE \\ Deperimeat of Enth

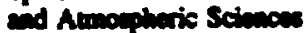 \\ Pudne Uivinity \\ Weat Lefoyme, IN 47907
}

\author{
N. G. W. $\cos$ \\ Depertureme of Mmmials Science

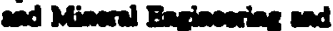 \\ Encth scionous Divicion

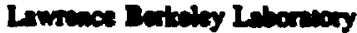 \\ Univerity of Cllifonia \\ Euteloy, Coliforita 94720
}

\author{
L. R. MYER \\ Emth Sciences Division \\ Luwrence Berkeley Laboravory \\ Darkelay, California 94720
}

\section{ABSTMACT}

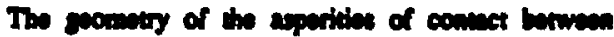

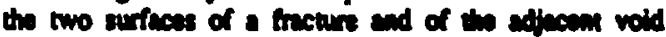
pacen dowrmians fuld flow trough a fretere and be

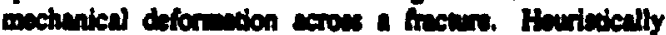

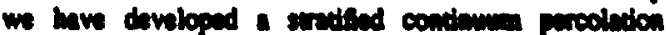

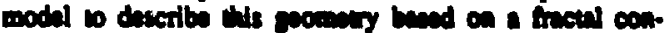

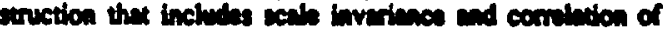

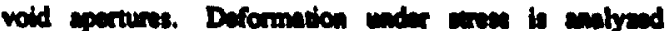

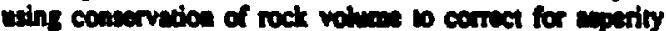

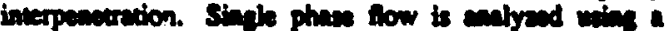
critical path slows which the principel melutence to a revilt of boiner fow exoss the critical soct in this path.

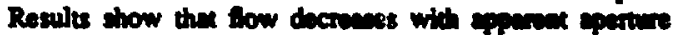

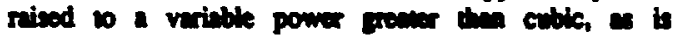
observed in tow experimeans on sand themes. For two phases, flow of the mormating ghase is likewise governed by the critical acek wong the crivical pech of

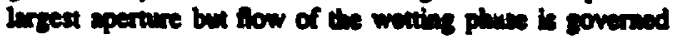
by rormosity. Relutive permebbility crive show stods

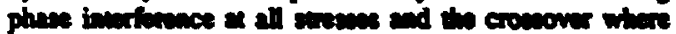

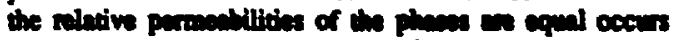

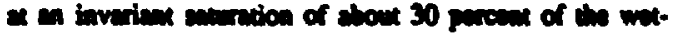
tiog phane.

\section{MIRODUCTION}

To bolus ligh-lovel redionctive wese th rocks

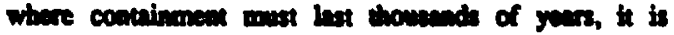

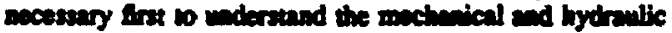
properties of a rock mese, both in the chort wme and the

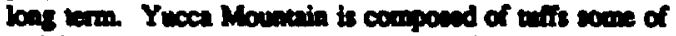
which are porous and oturs bavily tresured wille

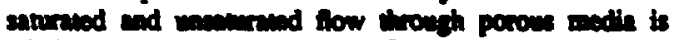

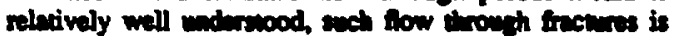

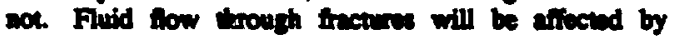
changes in the ano of the elivetive trues in a rock mas. Streswes a Yucen Mounsin could chares as a result of the excavation and enplacemeat of wers or as a revilt of veconic setivity, including fombing. In is importan for performance asesenemt to be able to calculate or prodict multighan fow trough trectires and the effects of cherime in utese, pose presurs, or pose volume on such Cow.

Fiud flow trough a mans is tundenonelly

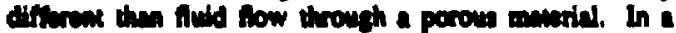

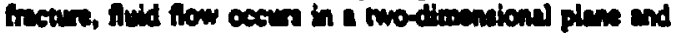

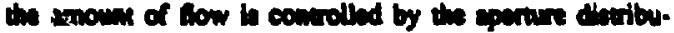

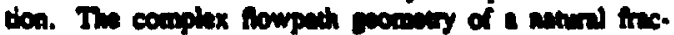

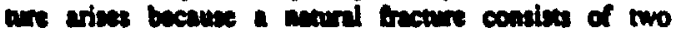

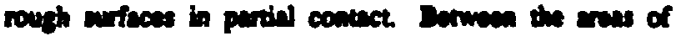

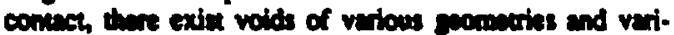

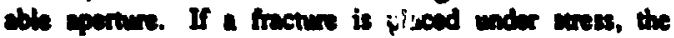
freture voids deform, which retults in at increate in contact eret, a reduction in wold aperume, and a reduction in trence void volume. Frecture enometry conterols the Bow of fluids through the fructure, the mechenical defor-

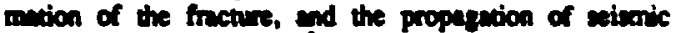
waves ecross the trecture.' The key ov undereanding the hydraulic, mochanical, and reisonic properies of netural froctures is 10 gundify the fructure soonetry ad to andartand bow fluid fow and deformeion propertias are coupled trough the finchere woplogy.

The vold soometry of a fructure will be infuenced by the roughness of the individual fncture anfeces ind the correlations between the two nribes. ${ }^{23}$ Other

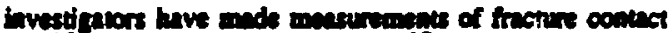

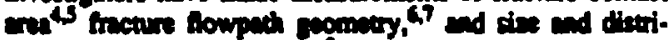

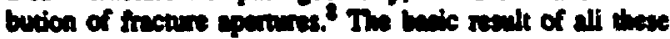

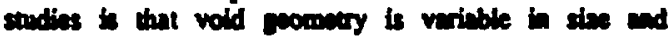
shape and the eomerery of the volds dowrmines Anid

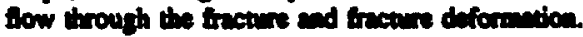

A standerd epprocect bes ben to model an'd bow through a incoure as if is were bomwen pealld pleses. In this approuch, tuid fow trough the theture is peryor. tional wo the cube of the apenture of the tructure ("cubic law"). Investigans have mode monarnenens of fluid tow through both induced fretures and anturl finchures and found relationships betwoen fuld fow and fucture aperture ipvolving on exponent much prower than 
cubic. 479.10 These discrepancies or deviations trom cubic Law behavior were curibued to veribble void cross-

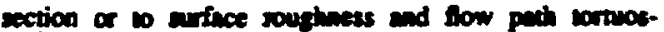
ity. 9.11

\section{MODEL DESCRIPTION}

Examples of the towpath poosetry in a manral tracture st three differeat suess levels we shown in Figure 1. Flowpuths (6illed with Wood's netel) are wive while conduct area is buck At the bowes stren (Fig. 1a) the contact ree sppens as ioland "idlends" of contect. As hipher stresess (Firs. Ib and c) these ane of contact

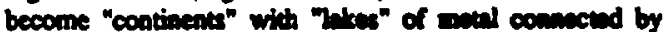

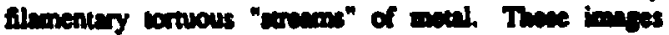
show that the distribution of voids end contect ans are

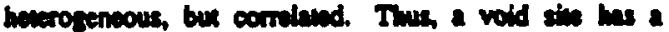
ligh probubility of being enrounded by other woid thes

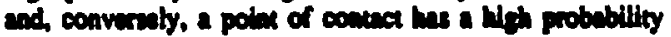

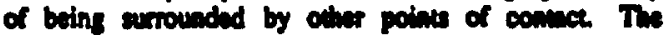

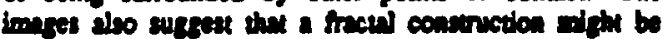

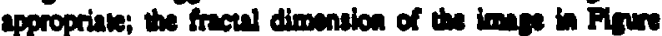
ic is 1.94 .
We have constructed a smatied continuum percolaion model 10 investigave flow in fractures and the changes in flow under verying stress. This approach incopporives the randocmess of stenderd continuum percolwion and and a finctal consuruction the reproduces the type of flow poometry obeerved in experiments. 12,13,14,15 A continunem model is used because the distribution of vaid uperures is continuous and there is no underlyins latice suncure in a tracture. A fructul construction is

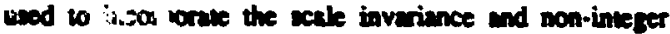
dimens in of f'ow peche obverved experimeatilly.

To :-F ' uet the flowpech peometry a patien is renenued by placins $\mathbf{N}$ madom siks within an mea celled a tive. Euch nase of twate sives represents the cencer of a now the which is sonller in tise then the preceding tier by a scale factor b. In each of the new tien, $N$ sines thes

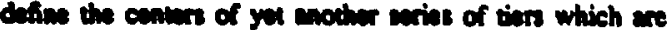
wenller then the preceding tion by the ecale fector b ane aghin midooly discribund. This proses can continue for as many dos as dosired. The thel rewlt is a convelued pasem. The pavem in Pigure 2 a represents a trencere under low stress bucause of the enell amount of conenct
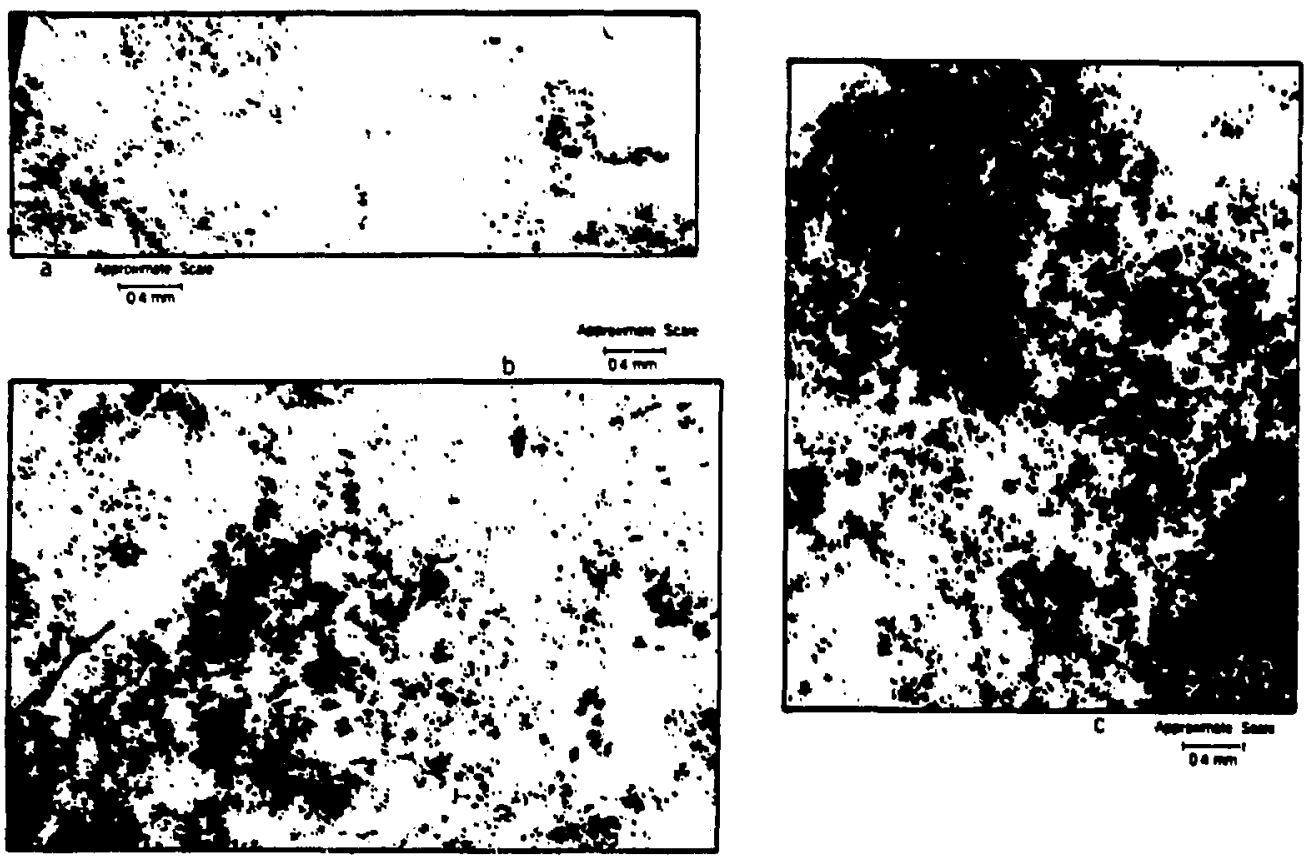

Figure 1. Composic from microjinghs of a partion of a netural fracture at effective atresses of (a) 3 MPa; (b) 33 MPr; and (c) 85 MP2. Wood's metal injection rechnique was used." 
aren This patern was generned waing a five tier model with twelve points per tier and a seale factor of 2.37 between tiers.
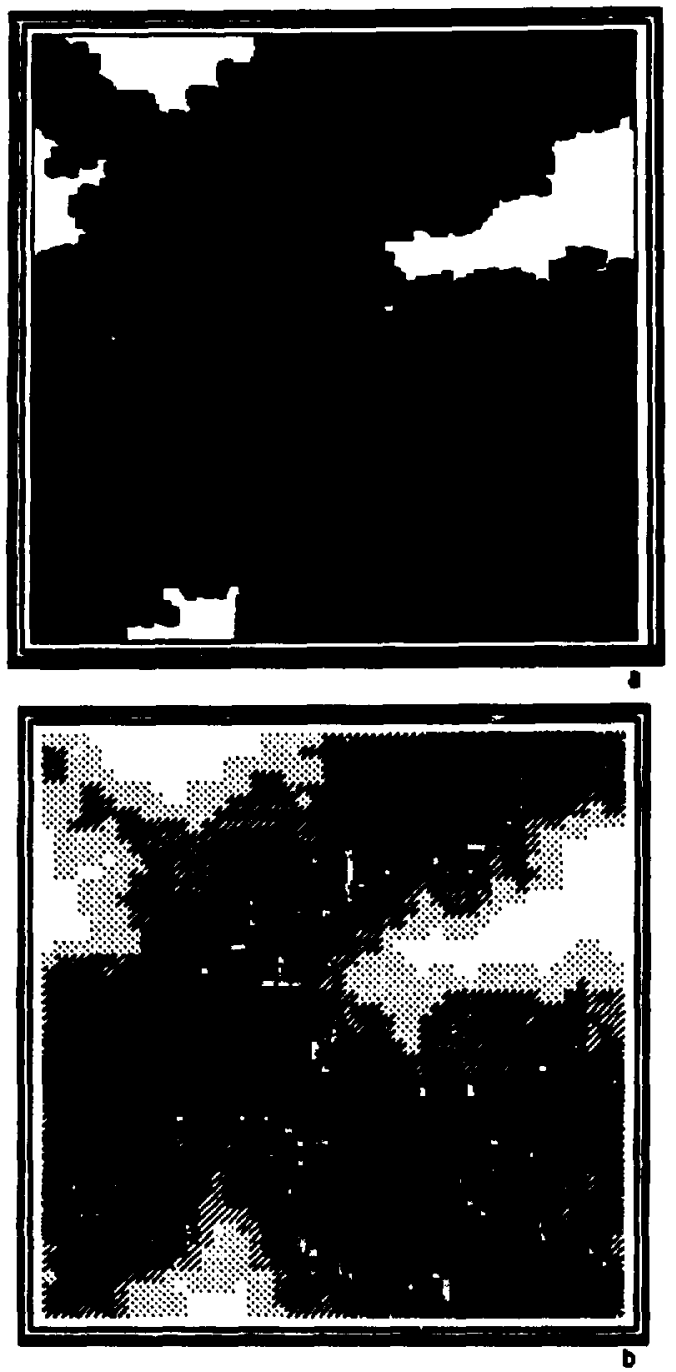

Figure 2. A stratified continum percolation model of void speces in a fucture under low stess; (o) Black represents the flow paths and the whice rejions represent contect are, $D=$ 1.99, (b) Aperture contour plot of pantern shown in (o) White regions represent conwet area, and increasing shades of eny vo bleck represent increasing eperture. Scale of concurr. 20 units of aperture.
On the find tier, as the points are being ploned wo construct the patem, points will overlap producing stratified pactern. The amount of overlap that occurs at each pixel of the patrem is counied and equated to fracwre aperture (erbitrery units). The eperture distribution of a genented pattern is relaved 0 the density of sites in the construction of the parem. Figure $2 b$ is a mup of the perture distribution of the pattern shown in Figure $2 a$. White weas in Figure $2 b$ represent contect wea and black areas represent sites of lerest aperture. It is observed the the eperture distribution is aso correland; that is, vies of lere epertures have a high probubilicy of being wroundad by other sives of large aperaures. In this paper we analyas fluid flow and mechanical deformation of the tneture flowputh seometry in Fifure 2. This flow path cometry resembles that in Figure IC and has a frect dinension of 1.99 at exo suress.

\section{SATURATED FUUT FLOW AND MECHANICAL DEFORMATION}

Previously, masurements of mochunical displacement and tuid flow through thre different maturl trectures in enmples of querts monsonite were cerried out." The how through these frectures was dividad into two perts; assem-independent irreducible fow and the remuining sperture-dependent flow. Fizure 3 shows the aperture-dependent portion of huid tow and changes in apperent aperture as a resull of increasing effoctive suress $\left(d_{\text {nem }}-d\right)$ on a be-los ploc. if fluid flow through the frectures were behaving as fluid fow between pardlel plaves (cubic law), the date would lie slong a line with slope of one thind Instead, the fluid now date devine troen cubic law betuvior and show a dependence on apparent mechunical tncture aperture much greater than cubic, numely, 7.6, 8.3 and 9.8.

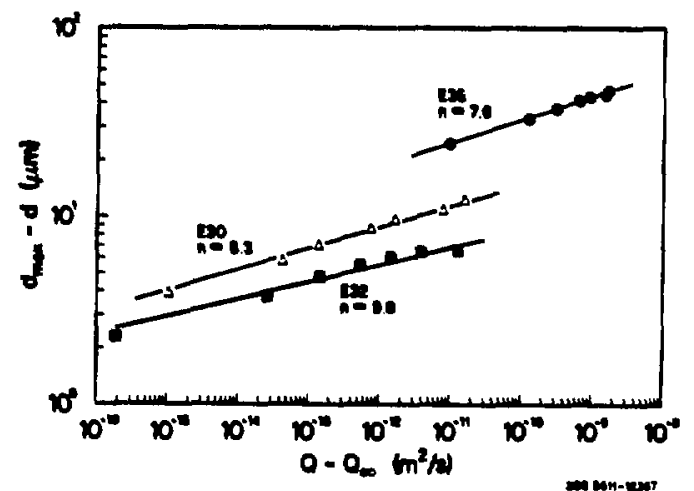

Figure 3. Frecture displecement versus flow per unit head drop afver subtenction of irreducible how for specimens E35, E30 and E32.6 


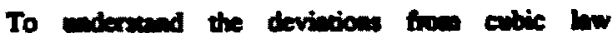
behavior of the flud flow, we malyad boh twid thow

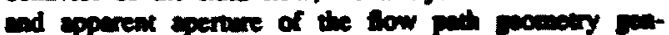

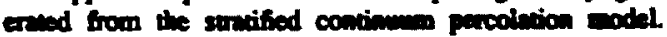

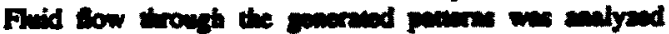

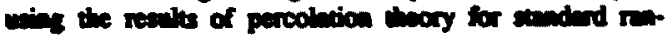

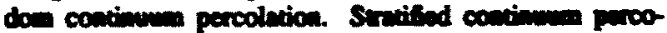

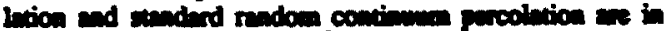

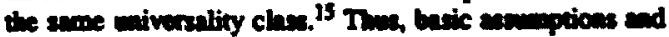

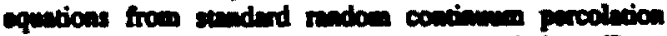

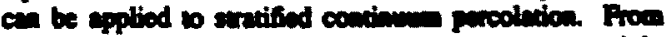

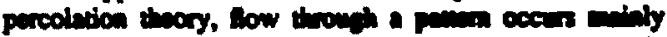

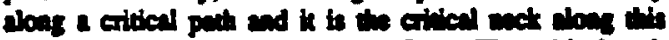

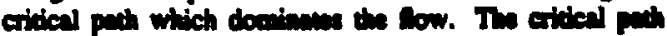

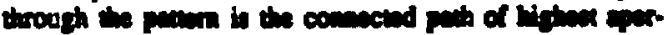

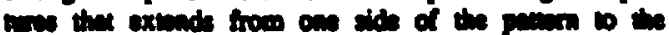

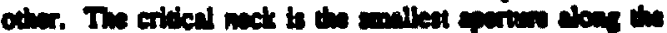

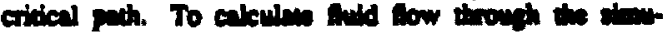

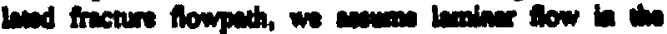

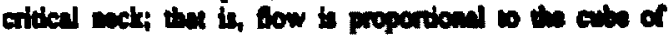
the eperver.

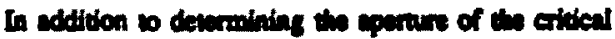

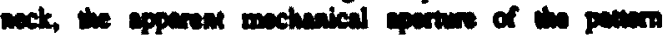

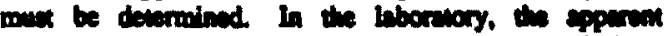

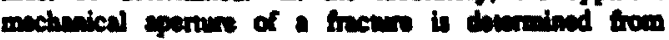

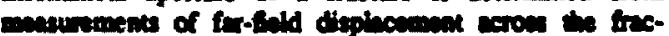

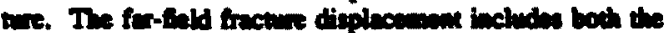
reduction in void epervers and the deformation of the

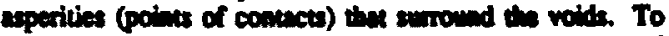
cocoun for the mechenieal daforumion of the pointe of

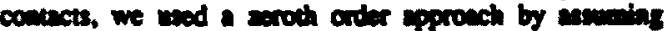

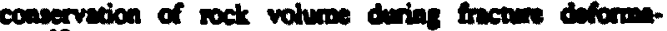
cion. 12 If the void apece is reduced one wit of perture, the menerial in the asperities does noc simply velbh or

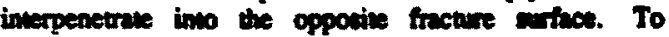
cccounk for this muerial, rock volume is conserved by

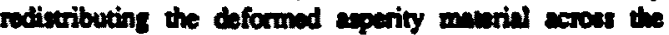
whole crosesection of the trecture. Tuns, the for-ield

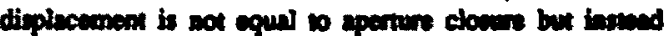

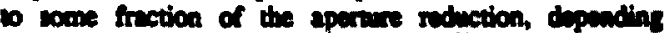

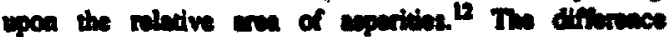

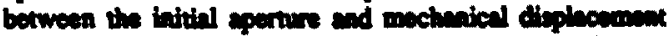

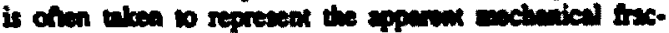

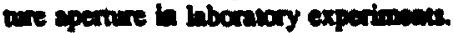

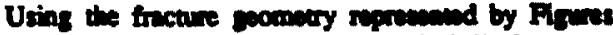

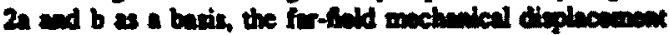

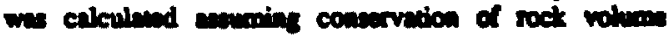

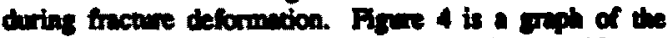

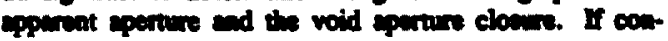

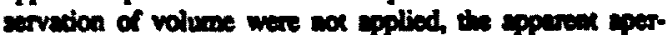
we and the void eperture clostre would be equal yialdlas the lineer relecionship shown in the fyore. Hownver. by asuming conservation of volume, a montianer neledon-

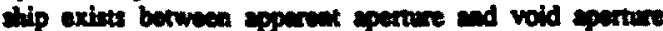

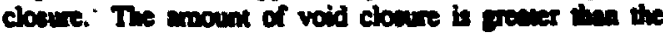

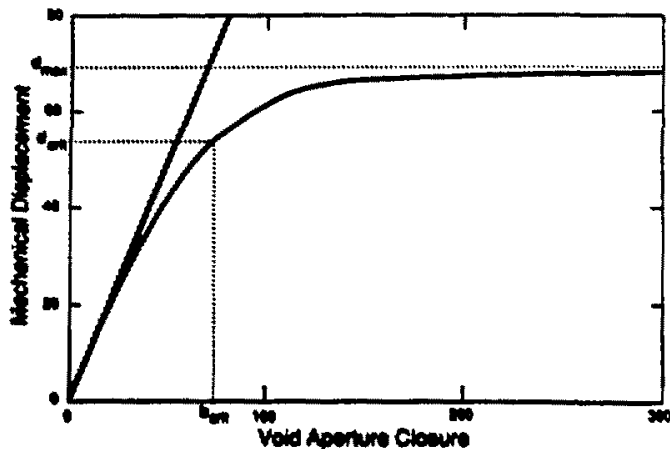

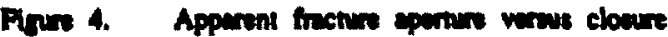
of vold space for paiven shown in Figure 2.

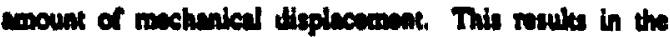

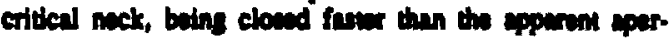
mo.

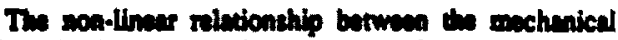
for-fiald displeceonent and the clowre of void sperture is

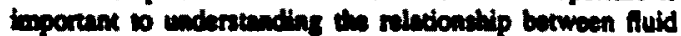
fow trough a trecture ad changes in epperem fracture aperure (Fis. 5). If thid bow trough a fructure depended on the cribe of the difiunce between the initid perture, $\left(d_{\text {max }}\right)$ and enchenical displecemen (i.e.,

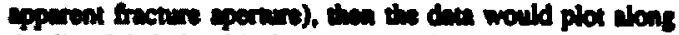
the bine hbeled cubic in Figun 5. However, if low per win hand is celculand band on the cube of the apernire of the critical mate be will as a function of spperent eperture, devivions trom cubic law will crive. The dovit.

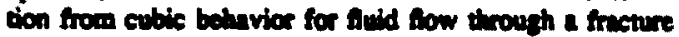
is a weult of the monlines mlationship between the

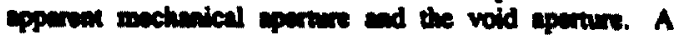

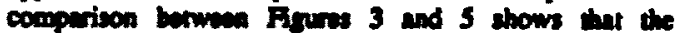
warly bivar part of Foure 5 a sull flows has a high nepaive exponem as does the crive for the experimental dut in Fine 3.

\section{UNSATURATED FLUID FLON}

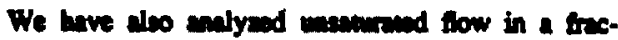

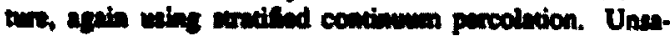
brend flow coess when then we nwo or bore pheses

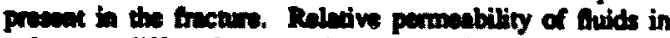
a fecture differs from relative permesbility of luids in a porous modium in that the tow pachs trrough a frecture it in two d'measions. We imvetigand the niletive per-

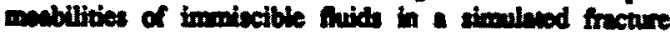
rometry and considered the effect of stress on relexive purmobilitios as do Pruess and Tung. 6 This invetige. ton does sot doal with invaion percolation or traping 


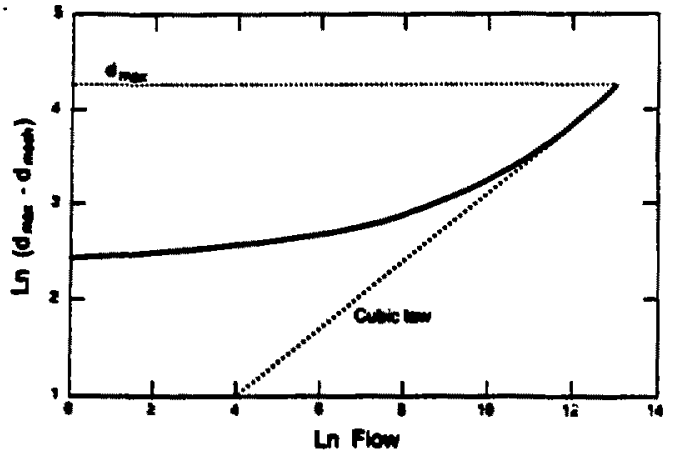

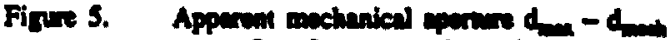

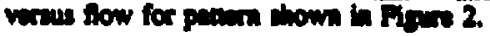

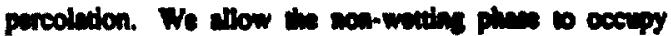
the lere volds and enmen mady-enen condidions when

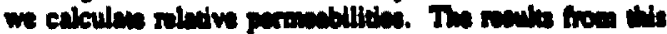

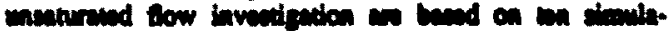

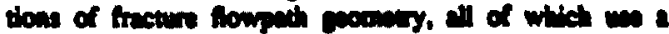

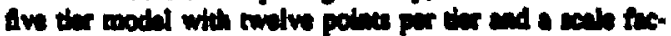

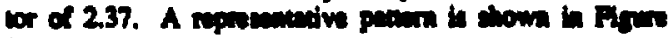
2.

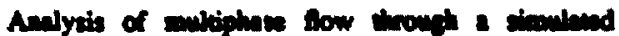

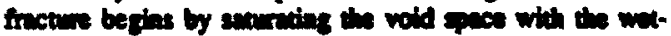

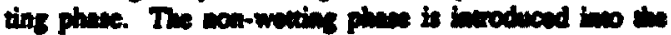

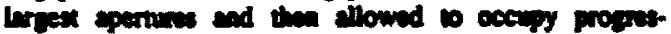

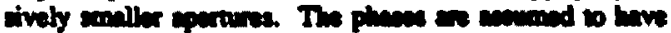

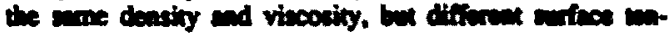
sions. As the won-weting phew is allowed ino sarler

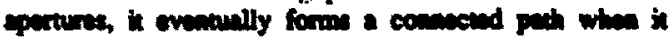

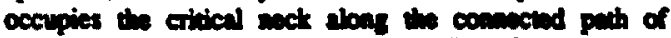

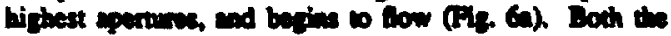

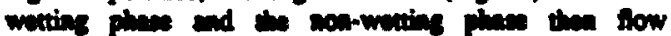
troungh the trecter. If the nom-weties phen is allownd

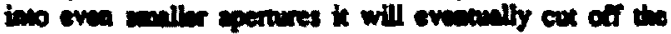
puncolatine pech of the wetting pheve which them cemest

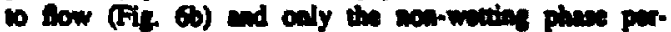
colves trough the tructire.

The fint cidicel mect for the wering phase, which is

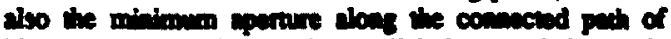

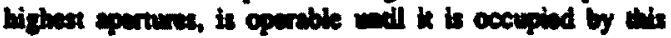
phise which thon begies to flow. When the mon-wneing

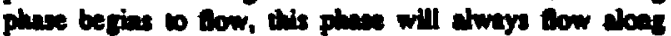

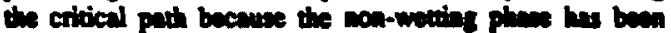

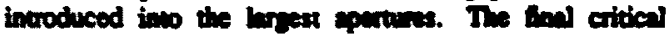
nock for the wetting phan is the critical connection thet mainuins a percolution path for the wetins phase. It opernes until stled with non-watios phase, centing the wetting phase to ceave to flow.

In order 10 denamine the neletive parmenbilities of

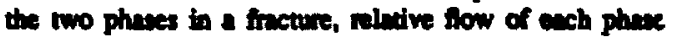

whe evaluned. To calculake fluid fow through the model, a zeroth order approuch is tuken which includes only the simplest dependences, which are: (1) the cubic law describes the bocel dependence of flow on aperture; and (2) the two-dimensional critical behavior is included by a
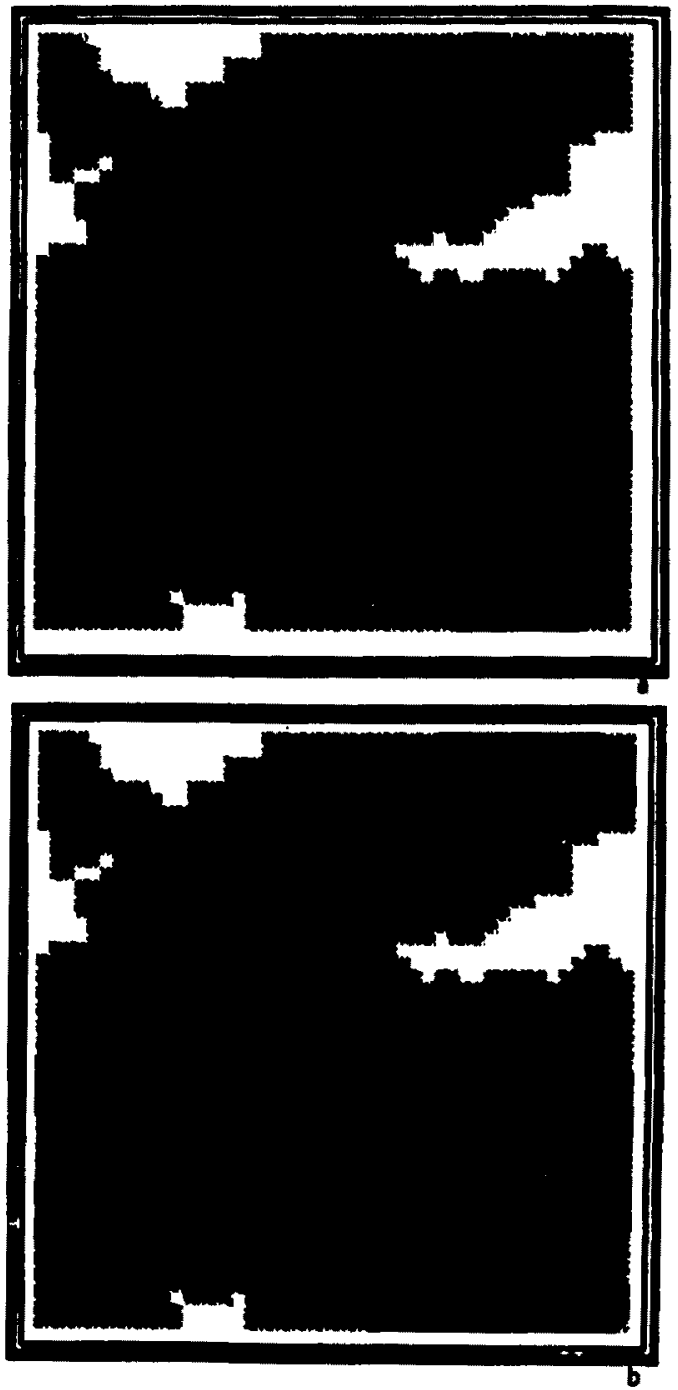

Figne 6ab. Depiction of ane of void spaces occupiod by veting phane (rny), soa-wetting phase (bluck), and combet urea (whice) for nonwetting phase in apettires leger then (o) 102 unit of eperture, and (b) 56 wits of eperane. 
- cealing law thet describes changing cornosity. Lamian.

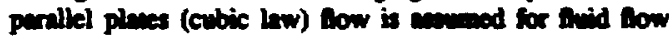
of both phases through the critical mect. Tormosity is important only for celculating the weting phan persuenbility becaure, at the non-wetting phane is introduced the wetting phase is robbed of is high sperture pech or crigi-

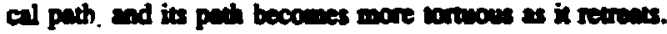

The expreacion for wexieg phan flow through the pareen is

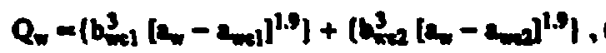

where

$$
\begin{aligned}
& \text { w - wroting pham } \\
& \text { c - critical } \\
& \text { Q - Dow }
\end{aligned}
$$

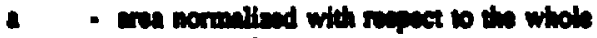

$$
\begin{aligned}
& \text { uren of the frectirs } \\
& \text { b - epernure of exilical nack }
\end{aligned}
$$

1 or 2 - Int or find crided mot

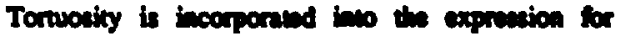
relative permability of the wowias pheie (Bq. (1))

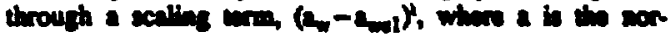

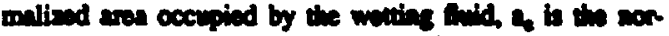

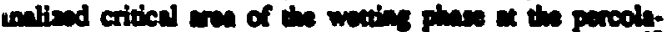

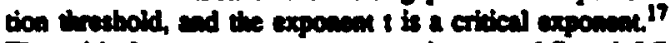
The critical exposenth h can mape bumm 1.7 and 27

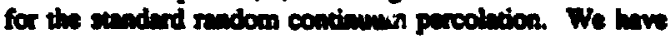
ateumed a value of 1.9 for the critical exponeme. This equation applias minly in the vicieity of the percolecion theshold.

The non-wetting phase low, in comrax is shmys

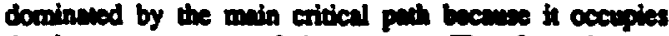

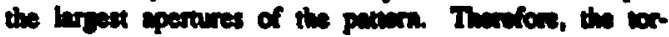

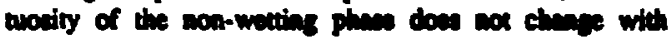

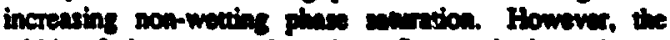

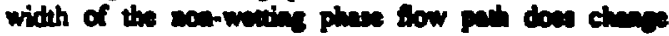

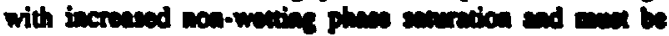
eccoumed for in the slative tow exponion. The exprescion for aca-weries phan fow (nw) is

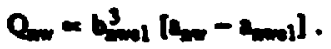

The exprevion for th nom-wotiog phase to sinply a cubic dependence on apernere and a limer dependamce on

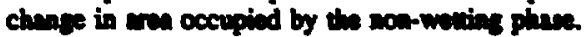

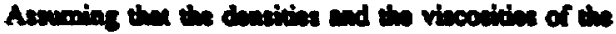
two phases are the anos, nlative permebllition for the

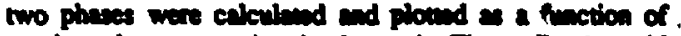
weting phase sanration is show in Fire 7. A npid

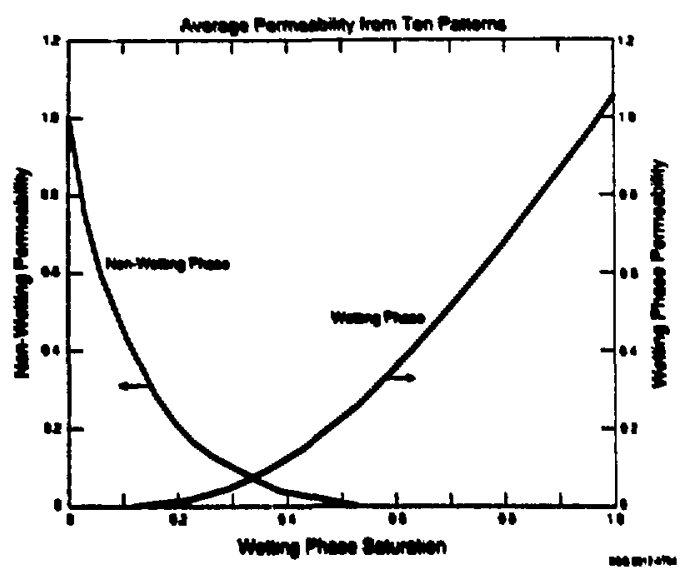

Figur 7. Relative permeabilitis of the non-wetting phase ad wetting phan as a function of wering phes sanidion.

decrese in son-woting phere perwoublity is obewred whth an increace in wetiag phese senration. For low

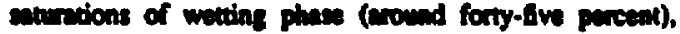
the non-wetting phase cences to Row. The crosustrex in permobilitios, where the permenbility of both phenes is

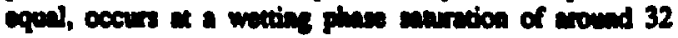
purcest.

The eficets of stres on reletive pormenblities of Duids in a frecture wes cvaluand by epplyines news to the

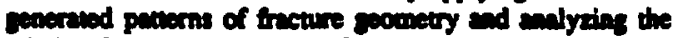
reletive flows. Application of tren is viewed at a joduc-

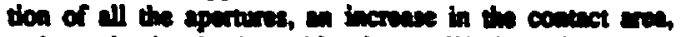
and a nduction in the vold volvone. We investipned to

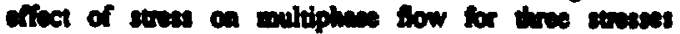

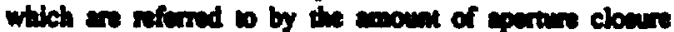
(5, 20, 50). A clowes of 50 mites of epertine is sbove a

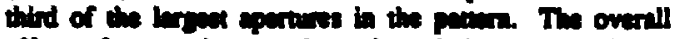

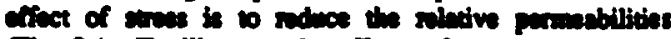

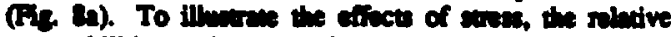

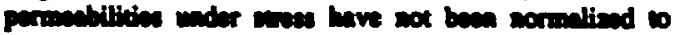

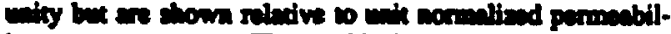

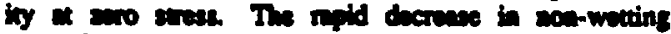

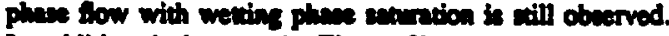
In adition it is wen in Figure to the the cross-over poidt is enemislly invarient with regect to wress. For Ill streses the crose-0ver occus between 26-32 percent wetiing phase morntion. For this model, this beads to the concluaion that if the percentage sanration of one of the phaves is known, one cen deverwine which phexe domivanes the flow at any ghess. 

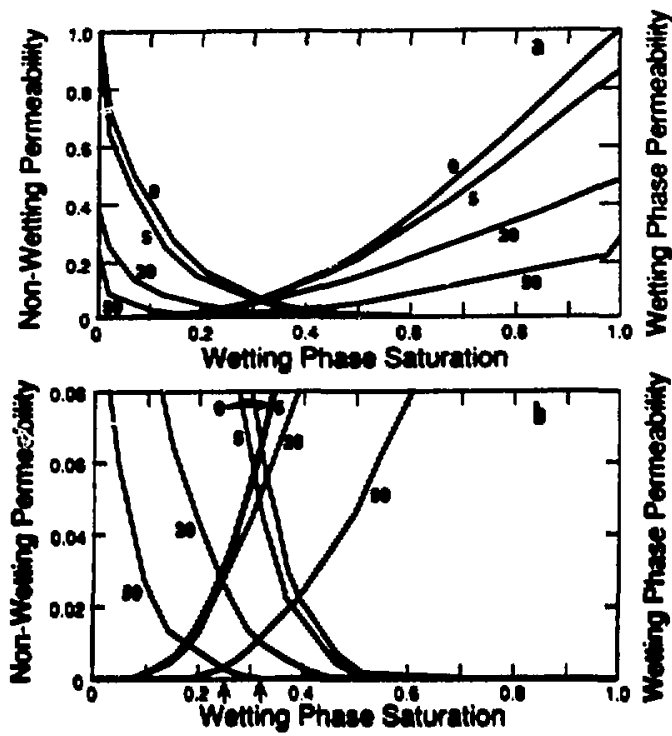

Figure 8a,b. Efiset of was (a) on relative parmeabilities for a reduction in apermine of 5,20 and 50 unit of eperture. (b) An enlergement of the cross-over repion of (a). The rrows indicate the minimum and maximum value of wetting phase surmetion for the crossovers in relutive permeabilities a a function of gtreas. The cross-owers in relutive permenbility are essentially inveriant of veres.

\section{CONCLUSTONS}

Using a model based on a tratel constnction, we were able to simulave the experimentally-obmenved fow path seometry of a trecture. The studifiad continum percolation model whe und becaun the procoletion properties are in the sume miveralioy class is those of

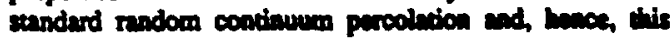
body of knowidge can be und o salyse frid how trough a tncture. Ine etretified parcolvion moded yiekds correlened aperure dierributions. Employing parco-

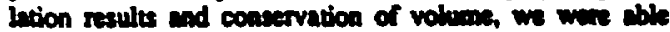
o understand deviations from covbis law bebmior the have been observed for anurand suid fow trough siaple

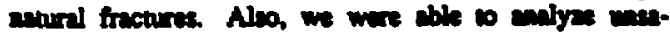

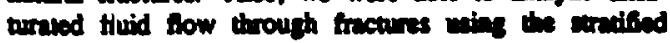
percolation model.

The relationship between belavior moneund on

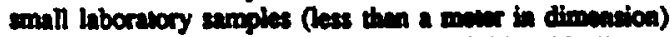
and fluid flow through fncures in the fild (with dimen- sions of peshaps kilometers) is not known. Clearly, this relutionship needs to be established if the results of resenrch to to have useful spplications. Many phenomena in soology have been shown to possess a large defree of scale invariance over a nnge of dimensions wuch as those of concem here. Fraculs have been used to describe these inveriant properties. The scale invariance of flow pachs and convect ereas in laboratory aumples of rock fucnures over a scile of ens of millimeter to hundrodths of millimeters bed us heuristically to propose a stratifed percolation model besed on a fructal construction 10 simulare the enometry of the roid spaces bermen trecture surfeces. This consenction has ben thown to replicate meny of the feetures of red tractures. The auraction of tie model is two fold. Finh it may cepture effectively those esential propertios of the void spece and contuct and tha remult from the renesis and subsequent wetemorphotis of trectures in rock. Second, It offers the prospect, trough evile inveriance, of trin. spoting the nesults of a saudy on a laboracory cale to the beld reale.

Chages in trackes sperture as a resule of changes in afictive sucs have been shown experimentlly to have a profound eftect on fluid flow. Cunrly, this derives trom chenpes in void spese exonetry broughe sbout by deformetion of the rock in the vicinity of the volds. In principle, for given mechanical properties of the rock, it is posable to calculate the changes in void eonetry as a function of effective mata. In procice, weh a calculation would be compunationally incensive and would require an unrensonably detrilad knowbedye of the void geometry. Afrin, the question rises whether or not a more simple model wight cepture the exwential seatures of the phenomens involved. The escencid process involved in the deformation is that the complex steas redistribution edjecent to the voids at a reath of this deformation does not involve any changes in the set voluene of the rock in this region. Twerefore, we chose to model changes in void eperrure so the the volure of rock would be con.

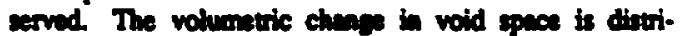
bued scross the whole projueted orea of the finctire to relawe it wo changes in meanud tracters eperture. The And abetrotion involves the une of a crided pech and a critical neck to enalym the resionnce o siaple phose flow or the resimace to the flow of a mon-wating phere, and ccaling to extimnte the efficts of wrucoity on the flow of the wetions phese for two phene sow.

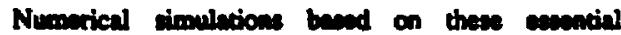
abenctions the it, the trectal construction of the void epeces, convervation of voluone of rock and the dominance of the criticel neck yield realts very similer to thoce oberved in loboniony exporiments. In perticuler, the relationship borween changes in menound (moshanical epernure) and roid cloure are shown to be con-biner, beading to much higher exponens between meanred apernure and flow than given by the cubic law. We have 
und a gimiler approach o derive the relative permeabilities of frectures for two-phase flow but as yet have no

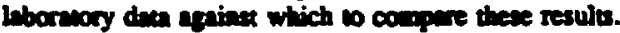

Though the imple epproach dencribed above has

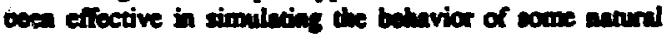
froctures in laboracory experiments, it sewains to be entablishod whether or not it is anficiendly effoctive and robust o describe a wider mase of labonwary experimease and of form the basis for extending this work o the feld. Clowrly, the luner requios some menturemeans on a field scile of the enowetry of the roid spacen and

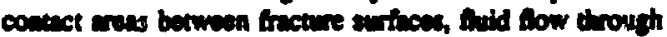

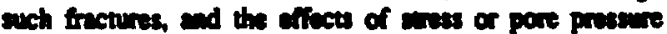
on tow. Hopefully, it will ulvimstely be posible (fo nol

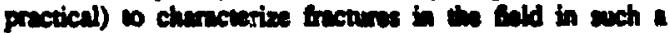

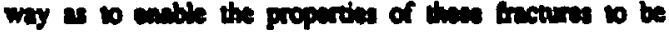
anyand with at dimple a wodel a dacribad.

\section{ACKNOWLEOMENTS}

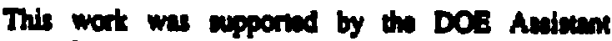

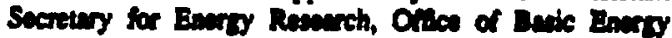

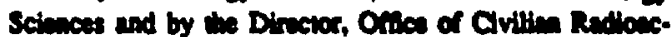
tive Wese Mengement, Orice of Fecilitios Bting ad

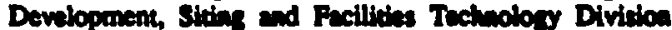
of the U.S. Depertunent of Berrs Cominct No. DEAC03-76SFoO0is.

\section{REFERENCES}

1. L. R. MYER, L. J. PYRAK-NOLTE, D. L. HOPXNS ad N. G. W. COOK, "Snimic Curnesuristion of Fece-

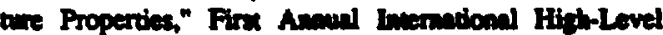

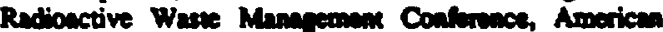
Nuclear Society (this volurns) (1990).

2. O. SWAN, Determination of Stiflness and Other Joint Propertien trom Rouphans Moenmumene," Rock Mechanics and Rock Enginesing, 16, p. 19-38 (1913).

3. S. R. BROWN, R. L. KRANZ ad B. P. BONNER, "Correlation between th Sufeces of Nimerl Rock Joins," Geoplysical Rawnch Lawers, 13, p. 1430-1434 (1946).

4. K. TWA, Fondenomens of Fuid Flow trough a Sim-

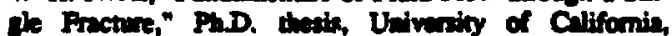
Bateley, Californic, 200 p. (1976).

5. S. C. BANDIS, A. C. LUMASDEN, ad N. R. BARTON, "Fundamentis of Rock Joint Deformetion," Imer. miond Journel of Rock Mechanics an Mining Science and Geomechenicel Abstrects, 20(6), D. 249-261 (1943).
6. L. J. PYRAK-NOLTE L R. MYER, N. G. W. COOK and P. A. WITHERSPOON, Hydrulic and Mochanical Properties of Netural Frnctures in Low Permeability Rock," in Proceedines, Imernational Socien for Rock Mechanics, 1. The Invernutional Congress on Rock Mecharics, Montreal, Canuda, p. 225-231, August 1987.

7. S. GENTIER, D. BILAUX AND L. VAN VLIET, "Laboranory Testing of the Voids of a Frucnure," w appear in Invernutional Journal of Rock Mochanics and Mining Science and Geowechunical Abstrects, (1989).

8. E. HAKAMD, "Water Flow in Single Rock Joints," Fh.D. theais, Lulen University of Technolory, Sweden, p. 99 (1988).

9. T. ENOELDER and C. H. SCHOL, Fuid Flow Alons Very Smooth Joint a Efrective Presure up vo 200 Mapapacels," in Mechanical Behuvior of Cruat Rocks. The Heatia Voluon Amorican Cucphyical Ualon Monopriph 24, p. 147-152 (1911).

10. K. O. Ravea and J. E. Gak, WWant flow in a Netural Roct Erecture as a Function of Stras and Semple Sise" Absench Inurnetiond d. Rock Mech. Min. Scl. Geomech., 22(4), pp. 251-261 (1945).

11. Y. W. Trons, The Efrect of Tonuodity on Fiud Flow though a Single Fructure," Wever Resources Research, 20(9), p. $1209-1215$ (194).

12. L. J. Pyon'-Nolle, N. G. W. Cook and D. D. Nolve

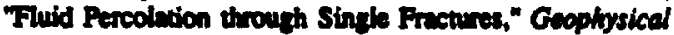
Reswarch Letwers, 15(11), p. 1247-1250. (1948).

13. D. D. NOLTE, L. J. PYRAK-NOLTE and N. G. W. COOK. "Fructul Fiow Puts in Rock and the Approsech to Percolation," Aburnct, EOS, American Gecphysical Union Transections, 67(44), p. 871. (1946).

14. D. D. NOLTE, L J. PYRAK-NOLTE ad N. G. W. COOK. "The Frnetal Geometry of Flow Paths in Netural Frectures in Rock and the Approach to Prociesion," Pure and Appliad Gecpinsics, 131(1/2), p. 111 (1999).

15. D. D. NOLTE, "Inverian Fived Point in Sinwifind Contiaurm Purcolmion," Repil Commmnications in Physt. cal Roview A, 4a, p. 417 (ises).

16. $K$. PRUESS and $Y$. W. TSANO, "On Two-Phue Relative Purmability and Capillery Presenre of RounthWallad Rock Pactures.' accepund for publicacion, Wever Resources Revemeh, (1990).

17. B. 1. HALPERDN , S. FENo and P. N. SEN, Differences between Lutice and Continuren Percoletion Trensport Exponeats," Phys. Rev. Lex. S4, Pp. 23912394 (1995). 


\section{DASCLAIMER}

- This document wa prepared as an eccount of work sponsored 'by the Uniled Sules Government. Neither the Unilod Sulst Government nof any wency thereof, nor The Resents of the Univeruity of Californita, nor any of theit employees, makes any warraty, express or implied, or amumes any keal liability or i responsibility for the accuracy, completenes, or usefulnes of any information, apperalus, product, or process dixloued, or 'represents that its use would not inftine privalely owned rights. 'Reference hereia to any specific commencial products proceste or iservice by its trade name, Iracemark, manufacturer, or other. ' wixe, does not necesserily consituve or imply its endorsement, 'recommendation, of avoring by the Uniked Sutes Government , or any exency thereof, or The Resents of the University of California. The views and opinions of authors expresed herein do ' not necesurily sule or refect those of the Unived Suales Government or any wency thereof os' The Revents of the University of California and shall not be used for adventing or product eiborsement purpotes.

Lawrence Barkeley Laboratory is an equal opportunity emptoyer. 